\title{
What Trucking Deregulation Did for Florida's Produce and Ornamentals 1
}

\section{Richard Beilock ${ }^{2}$}

From the late 1970s through the mid-1980s, economic regulation of interstate trucking was phased out in the United States. Prior to that time, trucking firms had to seek federal permission to haul many types of cargoes and there were restrictions on the rates that could be charged (note: in practice, rate restrictions prevented carriers from lowering their charges more often than the reverse). Deregulation of airlines occurred about the same time. Whenever a flight is delayed or a meal is either absent or not up to expectations, everyone loves to blame it on deregulation, rightly or wrongly. The same is true for trucking deregulation. This report will examine an important positive effect of deregulation on motor carriers and the Florida produce and ornamentals industries.

Produce and ornamentals were never among the commodities falling under federal regulation. Any carrier meeting safety requirements was (and still is) free to haul these commodities and to charge any fee it desired. While there were no direct effects on produce and ornamentals from federal regulation, there were on the cargoes truckers typically haul into Florida. For instance, when a carrier travels to Florida to pick up a load of produce or ornamentals, it tries to cover the costs by hauling any of the myriad of products Florida demands. This ranges from computers to red meats to pharmaceuticals to furniture to clothes. Over $80 \%$ of these inbound cargoes had been subject to federal regulation.

At the end of the regulatory era (in the early 1980s), just over a third of the truckers coming to Florida for produce or ornamentals were unable to secure an inbound load. For those truckers to keep coming to Florida month after month, year after year, the costs of those empty movements had to be covered. Undoubtedly that was done through higher freight rates for hauling Florida produce/ornamentals. Higher freight rates translate into lower net returns for Florida agriculturalists.

Why were so many trucks coming into Florida empty? It certainly was not for a lack of loads because Florida is a net importer of goods from virtually every other U.S. state and Canadian province (Kilmer, Ramirez, and Steglin, 1983). Rather, it appears that economic regulation made it difficult for some carriers to get loads. For example, barely one-fifth of the owner-operators who haul produce and ornamentals had federal permits (called Operating Authority) to transport regulated commodities.

1. This is EDIS document, FE544, a publication of the Department of Food and Resource Economics, Florida Cooperative Extension Service, Institute of Food and Agricultural Sciences, University of Florida. Published March 2005. Please visit the EDIS website at http://edis.ifas.ufl.edu.

2. Richard Beilock, Professor, TDepartment of Food and Resource Economics, Florida Cooperative Extension Service, Institute of Food and Agricultural Sciences, University of Florida, Gainesville, FL.

The Institute of Food and Agricultural Sciences is an equal opportunity/affirmative action employer authorized to provide research, educational information and other services only to individuals and institutions that function without regard to race, color, sex, age, handicap, or national origin. For information on obtaining other extension publications, contact your county Cooperative Extension Service office. Florida Cooperative Extension Service/Institute of Food and Agricultural Sciences/University of Florida/Christine Taylor Waddill, Dean. 
Throughout the 1980s and 1990s, as regulatory controls eased and were eliminated and the motor carrier industry adjusted, the percent of trucks entering Florida empty fell dramatically (Figure 1). Today, instead of one in every three trucks entering Florida empty, only one in twenty is empty. There can be little doubt that, because of this, freight rates for Florida produce and ornamentals today are significantly lower because of deregulation.

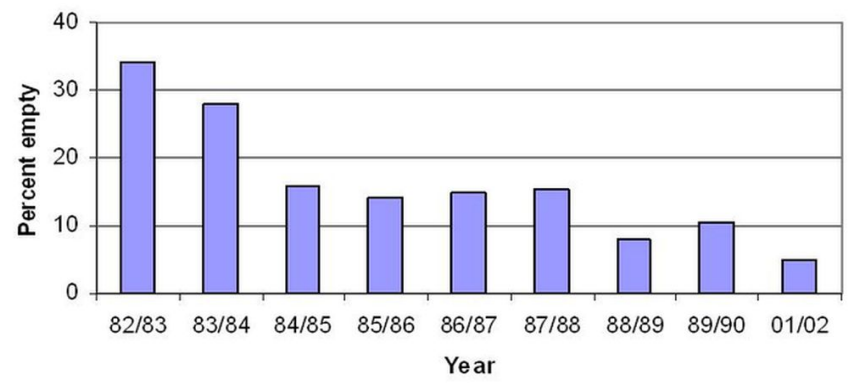

Figure 1. Percentage of trucks entering Florida empty.

\section{References}

Beilock, R. 2004. Long Distance Refrigerated Trucking: A Florida Case Study. Report prepared for the Agricultural Marketing Service, United States Department of Agriculture, Washington, D.C.

Beilock, R., J. MacDonald, and N. Powers. 1988. An Analysis of Produce Transportation: A Florida Case Study. ERS/USDA Agricultural Economic Report 597, Washington, D.C., 43 pp.

Jones, J., R. Fullerton, and R. Beilock. 1992. U.S. Trucking Review: Performance, Structural Change, and Deregulation. Canadian Institute of Guided Ground Transport Report No. 92-3. Queens College, Kingston, Ontario, Canada.

Kilmer, R., H. Ramirez, and F. Steglin. 1983. Economic Impact of Empty Backhauls in Florida Fresh Fruit and Vegetable Truck Transportation. Florida Experiment Station Bulletin No. 833, University of Florida, Gainesville, FL.

Kling, R. 1988. Trucking Deregulation: Evolution of a New Power Structure. Journal of Economic Issues 22(4):1201-1211.

Ying, J., and T. Keeler. 1991. Pricing in a Deregulated Environment. RAND Journal of Economics 22:264-273.

\section{Appendix: Data}

The 2001/2002 Driver Survey: This survey was conducted in November of 2001, and in January, March, and May of 2002. The survey sites included the Florida Agricultural Inspection Stations located on interstate highways U.S. I-10, U.S. I-75, and U.S. I-95. The drivers of 1,642 refrigerated tractor-trailers were interviewed as they exited the Florida Peninsula.

While the survey sites were all in Florida, the study has relevance for long-distance haulage throughout North America. The sample contained drivers from all 48 contiguous U.S. states and 8 Canadian provinces. These drivers were enroute to destinations in 46 states, the District of Columbia, and 7 Canadian provinces. Trip distances ranged from 100 to 3,347 miles, averaging 1,222 miles. 